\title{
OPTIMASI PRODUKSI TEPUNG PORANG DARI CHIP PORANG SECARA MEKANIS DENGAN METODE PERMUKAAN RESPONS
}

\author{
ANNI FARIDAH ${ }^{1}$, SIMON BAMBANG WIDJANARKO ${ }^{2}$, AJI SUTRISNO ${ }^{3}$, DAN BAMBANG SUSILO ${ }^{4}$ \\ ${ }^{1}$ Fakultas Teknik Univeritas Negeri Padang, \\ ${ }^{2}$ Fakultas Teknologi Pertanian, Universitas Brawijaya, Malang \\ Laman: faridah.anni@gmail.com
}

\begin{abstract}
ABSTRAK
Umbi porang (Amorphophallus oncophyllus) mengandung kadar glukomanan yang cukup tinggi dan sangat berguna bagi industri pangan, nonpangan maupun kesehatan. Masalah utama dalam pengembangan tepung porang yaitu adanya kalsium oksalat yang menyebabkan rasa gatal, iritasi dan gangguan kesehatan. Optimasi penurunan kalsium oksalat pada proses penepungan untuk memproduksi tepung porang secara mekanis menggunakan stamp mill dan fraksinasi blower. Optimasi dilakukan dengan metode permukaan respons (RSM), Rancangan Komposit Pusat pada tiga variabel yaitu berat chip, waktu/lama dan kecepatan penumbukan dengan respons kadar kalsium oksalat. Model respons adalah kuadratik dengan kondisi optimum berat chip porang 1,3 kg, 17,4'8', dan kecepatan penumbukan 19,23. Respons kadar kalsium oksalat pada kondisi optimum ini diprediksi sebesar 0,2978\% dan aktual 0,3\%, menurun 95,12\%.
\end{abstract}

Kata kunci: kalsium oksalat, tepung porang, optimasi, mekanis

\begin{abstract}
Porang Tuber (Amorphophallus oncophyllus) has high Glucomanan content which is very useful in food and non food industry as well as in medical industry. The only main problem in development of porang flour is its Calcium Oxalate content that stipulates irritation (itchiness) and health disorder. Optimization study of diminution (reduction) content of Calcium Oxalate during mechanical grinding process using stamp mill and blowing fractionation. Optimization was performed by applying Response Surface Model (RSM), central composite model. Three variables i.e. weight of porang chip, grinding time and grinding speed were studied in order to study the Calcium Oxalate content as a response. Response model obtained was quadratic which was acquired at $1.3 \mathrm{~kg}$ porang optimum weight; grinding time 17.4'8"; and grinding speed at 19,23 rpm. Optimum Calcium content has been predicted at $0.2978 \%$ which was $0.3 \%$ in actual, decrease $92,12 \%$
\end{abstract}

Key words: calcium oxalate, porang flour, optimization, mekanis

\section{PENDAHULUAN}

Umbi porang (Amorphophallus oncophyllus) termasuk tanaman umbi famili Araceae yang mengandung glukomanan cukup tinggi (15-64\% basis kering). Zhang dkk. (2005) menjelaskan bahwa umbi porang digunakan sebagai bahan baku makanan dan industri sejak 1.000 tahun yang lalu di Jepang dan China. Tingginya kandungan glukomanan dalam umbi porang membuat tanaman ini banyak dicari terutama industri pangan dan kesehatan. Katsuraya dkk. 2003; Gao dan Nishinari, 2004; Yang dkk., 2006 menyebutkan bahwa glukomanan merupakan makanan dengan kandungan serat larut air yang tinggi, rendah kalori dan bersifat hidrokoloidnya yang khas. Pemanfaatan umbi porang menjadi tepung merupakan salah satu pilihan untuk memudahkan penyimpanan serta pengolahannya lebih lanjut.

Masalah utama yang dihadapi dalam pengembangan tepung porang sebagai bahan pangan di Indonesia adalah adanya kalsium oksalat. Kalsium oksalat pada tepung porang menyebabkan rasa gatal dan iritasi saat dikosumsi. Konsumsi makanan yang mengandung kalsium oksalat dapat menyebabkan kristalisasi dalam ginjal dan gangguan-gangguan kesehatan lainnya (Bhandari dkk., 2002; Nakata, 2003).

Eri (2007) dan Gossy (2009) melaporkan bahwa penepungan chip porang telah dilakukan menggunakan blender, hammer mill dan stamp mill. Metode penepungan yang dilakukan dengan hammer mill belum maksimal dalam memisahkan kalsium oksalat $(0,8 \%)$ yang menempel kuat dengan dinding sel glukomanan (Gossy, 2009). Penepungan dengan stamp mill lebih banyak menurunkan kalsium oksalat dari tepung porang dibanding dengan alat yang lainnya.

Penelitian menggunakan metode penepungan dengan stamp mill yang berprinsip penumbukan. 
Keunggulan penggunaan stamp mill adalah pada bagian kepala penumbuknya terdapat lempengan mika yang dipasang melingkar. Lempeng mika menghembuskan serbuk-serbuk kalsium oksalat dan komponen komponen penyusun lain yang ringan saat terjadi proses penumbukan. Proses ini dapat membantu mengurangi keberadaan kalsium oksalat dalam tepung porang.

Chip porang ditepungkan menggunakan stamp mill dengan prinsip kerjanya adalah penumbukan atau menekan, kemudian fraksinasi menggunakan metode hembusan untuk menghasilkan glukomanan yang lebih murni (Gossy, 2009). Metode hembusan menggunakan aliran udara yang bergerak untuk memisahkan pengotor dari tepung berdasarkan perbedaan massa, densitas dan ukuran partikel. Glukomanan merupakan polisakarida yang mempunyai bobot jenis serta ukuran partikel terbesar dan bertekstur lebih keras bila dibandingkan dengan partikel-pertikel komponen tepung porang lainnya. Optimasi proses pemurnian glukomanan secara mekanis dengan tujuan penurunan kalsium oksalat, pati, protein, dan abu, saat penepungan menggunakan stamp mill kemudian fraksinasi blower.

\section{METODE}

\section{Tempat, Bahan, dan Alat}

Penelitian dilaksanakan di laboratorium Biokimia dan Nutrisi, laboratorium mikrobiologi Hasil Pertanian Jurusan Teknologi Hasil Pertanian, laboratorium Sentral Ilmu hayati Universitas Brawijaya Malang. Uji kemurnian menggunakan SEM dilakukan di laboratorium FMIPA Universitas Negeri Malang.

Bahan baku yang digunakan pada penelitian ini adalah umbi porang dengan diameter $8-19 \mathrm{~cm}$, panjang 5-10 cm, berat 500-2500 gr, warna daging kuning dari Perhutani desa Sugihwaras kecamatan Ngluyu kabupaten Nganjuk. Bahan kimia yang digunakan untuk proses pemurnian tepung porang diperoleh dari Laboratorium Biokimia dan Nutrisi Jurusan Teknologi Hasil Pertanian Universitas Brawijaya dan CV. Brataco jalan Hamid Rusdi no 11 Malang. Bahan kimia dengan kemurnian pro-analisa (p.a.) antara lain: seperti $\mathrm{NaOH}$, asam format, $\mathrm{HCl}$ pekat (37\%), $\mathrm{H}_{2} \mathrm{SO}_{4}$ pekat (95\%), $\mathrm{CaCl}_{2}$, indikator metil red, indikator phenolphetaline (pp), $\mathrm{NH}_{4} \mathrm{OH}$, tablet kjedahl,dan asam dinitrosalisilat (DNS). Bahan kimia dengan kemurnian teknis antara lain aquades dan kertas saring.

Alat-alat yang digunakan untuk pembuatan tepung porang dari umbi porang adalah slaicer/pisau, timbangan, stamp mill, blower, ayakan 30 mesh, pengering kabinet. Stamp mill yang digunakan dilengkapi dengan sebuah inverter untuk mengontrol kecepatan putaran motor dimana jika kecepatan 16, 18 dan 20 pada inventer maka kecepatan penumbukan berturut-turut 70,78 dan 86 tumbukan permenit. Peralatan untuk analisa adalah timbangan analitik Denver instrumen M-310, kompor listrik, termometer, bola hisap merienfiel, oven WTB binder, desikator Buchi K-314, water bath Soxhlet Memmert, stirer, plastik transparan, colour reader minolta CR100, muffle Ney M-525 Series II, mikroskop polarisasi merk Nikon seri BH2, sentrifuge EBA 8, glassware, cawan pengabuan, viskosimeter, dan Scanning Electron Microscopy (JSM T-100, JEOL, Jepang).

\section{Rancangan Penelitian}

Optimasi penurunan kalsium oksalat pada proses penepungan untuk memproduksi tepung porang secara mekanis menggunakan stamp mill dan fraksinasi blower dengan metode permukaan respons (RSM) dengan Rancangan Komposit Pusat. Tiga variabel yang dikaji pada penelitian ini adalah berat chip porang, waktu/lama penumbukan, dan kecepatan stamp mill. Titik tengah perancangan penelitian diambil dari berat chip porang, dan waktu/ lama penumbukan dan kecepatan penepungan terpilih dari penelitian (Nyoman, 2010). Oleh karena itu percobaan dakian tercuram tidak perlu dilakukan.

Kode -1, 0 dan 1 merupakan simbol yang menunjukkan nilai dari masing-masing variabel. Kode -1 menunjukkan nilai terendah (minimum), kode 0 menunjukkan nilai tengah (optimum) dan kode 1 menunjukkan nilai tertinggi (maksimum). Pada percobaan ini $\mathrm{x}_{1}$ merupakan variabel berat chip dengan kode -1 (1 kg), 0 (1,5 kg) dan 1 (2 kg), kode $\mathrm{x}_{2}$ merupakan variabel waktu penumbukan dengan kode -1 (12 jam), 0 (15 jam) dan 1 (18 jam), $\mathrm{x}_{3}$ merupakan variabel kecepatan penumbukan dengan kode -1 (16), 0 (18) dan 1 (20).

Seluruh perlakuan terdiri dari 20 proses penumbukan dimana setiap kondisi proses mengikuti rancangan percobaan rancangan komposit pusat (Tabel 1). Data yang diperoleh dianalisis menggunakan software Design expert versi 7,1.

Model umum rancangan yang digunakan adalah:

$\mathrm{Y}=\beta_{0}+\sum_{\mathrm{i}=1}^{\mathrm{k}} \beta_{\mathrm{i}} \mathrm{X}_{\mathrm{i}}+\sum_{\mathrm{i}=1}^{\mathrm{k}} \beta_{\mathrm{ii}} \mathrm{X}_{\mathrm{i}}^{2}+\sum_{\mathrm{i}=1, \mathrm{j}=2}^{\mathrm{k}-1, \mathrm{k}} \beta_{\mathrm{i}, \mathrm{j}} \mathrm{X}_{\mathrm{i}} \mathrm{X}_{\mathrm{j}}+\varepsilon$

Dimana $Y=$ respons pengamatan, $\beta 0=$ intersep, $\beta \mathbf{i}=$ koefisien linier, $\beta \mathbf{i}=$ koefisien kuadratik, $\beta \mathrm{ij}=$ koefisien interaksi perlakuan, $\mathrm{Xi}=$ kode perlakuan untuk faktor ke-i, $\mathrm{Xj}=$ kode perlakuan untuk faktor $\mathrm{ke}-\mathrm{j}, \mathrm{k}=$ jumlah faktor yang dicobakan. 
Penyortiran umbi porang untuk memisahkan yang baik dan yang busuk, kemudian pencucian dan pengirisan setebal $(0,5-1 \mathrm{~cm})$ yang dilanjutkan dengan pengeringan menggunakan pengering kabinet (6-8 jam) dan ini disebut chip porang. Penumbukan chip porang dengan berat, waktu dan kecepatan seperti Tabel 1 untuk mengetahui optimasi proses penurunan kalsium oksalat pada tepung porang selama penepungan secara mekanis. Melakukan fraksinasi tepung porang dengan memasukkannya kedalam hembusan pemisah (blower) sehingga diperoleh dua fraksi yaitu fraksi ringan dan fraksi berat. Pengkajian komponen tepung fraksi berat yaitu dengan menganalisa kadar glukomanan, protein, pati, kadar air, viskositas, melihat granula glukomanan dan pengotornya melalui mikroskop dan SEM saat optimal.

Tabel 1. Rancangan Komposit Pusat Ordo Kedua dengan Tiga Faktor

\begin{tabular}{rccccccc}
\hline No & $\begin{array}{c}\text { Berat } \\
\text { (kg) }\end{array}$ & $\mathbf{X}_{1}$ & $\begin{array}{c}\text { Waktu } \\
\text { (jam) }\end{array}$ & $\mathbf{X}_{2}$ & Kec & $\mathbf{X}_{3}$ & $\begin{array}{c}\text { Ca- } \\
\text { oksalat/ } \\
\text { Y (\%) }\end{array}$ \\
\hline 1 & 2.34 & $+1,682$ & 15.00 & 0 & 18.00 & 0 & \\
2 & 1.50 & 0 & 9.95 & $-1,682$ & 18.00 & 0 & \\
3 & 1.50 & 0 & 15.00 & 0 & 14.64 & $-1,682$ & \\
4 & 1.50 & 0 & 15.00 & 0 & 18.00 & 0 & \\
5 & 2.00 & +1 & 18.00 & +1 & 20.00 & +1 & \\
6 & 2.00 & +1 & 12.00 & -1 & 16.00 & -1 & \\
7 & 1.50 & 0 & 15.00 & 0 & 18.00 & 0 & \\
8 & 1.50 & 0 & 15.00 & 0 & 18.00 & 0 & \\
9 & 0.66 & $-1,682$ & 15.00 & 0 & 18.00 & 0 & \\
10 & 1.00 & -1 & 12.00 & -1 & 20.00 & +1 & \\
11 & 1.50 & 0 & 15.00 & 0 & 18.00 & 0 & \\
12 & 1.50 & 0 & 15.00 & 0 & 18.00 & 0 & \\
13 & 1.00 & -1 & 12.00 & -1 & 16.00 & -1 & \\
14 & 1.00 & -1 & 18.00 & +1 & 16.00 & -1 & \\
15 & 2.00 & +1 & 18.00 & +1 & 16.00 & -1 & \\
16 & 2.00 & +1 & 12.00 & -1 & 20.00 & +1 & \\
17 & 1.50 & 0 & 15.00 & 0 & 18.00 & 0 & \\
18 & 1.50 & 0 & 20.05 & $+1,682$ & 18.00 & 0 & \\
19 & 1.50 & 0 & 15.00 & 0 & 21,36 & $+1,682$ & \\
20 & 1.00 & -1 & 18.00 & +1 & 16.00 & 0 & \\
\hline & & & & & & & \\
\end{tabular}

\section{HASIL DAN PEMBAHASAN}

Optimasi dilakukan dengan menggunakan Rancangan Komposit Pusat pada Metodologi Permukaan Respons. Faktor yang dikaji adalah berat chip porang, lama dan kecepatan penumbukan. Tabel 2 menunjukkan respons yang dihasilkan.

\section{Pemilihan Model yang Sesuai}

Metode permukaan respons digunakan untuk menentukan model yang sesuai untuk memprediksi respons. Montgomery (2003) menjelaskan bahwa analisis model digunakan untuk menentukan model yang sesuai dalam metode permukaan respons. Model yang diperoleh dapat digunakan untuk memprediksi respons (kadar kalsium oksalat\%) untuk berat chip, lama penumbukan dan kecepatan penumbukan tertentu. Model yang dievaluasi mencakup linear, 2FI (interaksi), kuadratik, atau kubik. Proses pemilihan model dilakukan berdasarkan: uraian jumlah kuadrat (JK) dari urutan model (sequential model sum of square), uji simpangan model (lack of fit test), dan ringkasan model secara statistik (model summary statistics).

Tabel 2. Respons Kalsium Oksalat Komposit Pusat Ordo Kedua dengan Tiga Faktor

\begin{tabular}{rcccc}
\hline No & Berat (kg) & Waktu (jam) & Kec. & Ca-oksalat (\%) \\
\hline 1 & 2.34 & 15.00 & 18.00 & 5,17 \\
2 & 1.50 & 9.95 & 18.00 & 2,07 \\
3 & 1.50 & 15.00 & 14.64 & 2,07 \\
4 & 1.50 & 15.00 & 18.00 & 0,53 \\
5 & 2.00 & 18.00 & 20.00 & 2,03 \\
6 & 2.00 & 12.00 & 16.00 & 3,61 \\
7 & 1.50 & 15.00 & 18.00 & 0,51 \\
8 & 1.50 & 15.00 & 18.00 & 0,3 \\
9 & 0.66 & 15.00 & 18.00 & 0,51 \\
10 & 1.00 & 12.00 & 20.00 & 0,51 \\
11 & 1.50 & 15.00 & 18.00 & 0,53 \\
12 & 1.50 & 15.00 & 18.00 & 0,92 \\
13 & 1.00 & 12.00 & 16.00 & 3,67 \\
14 & 1.00 & 18.00 & 16.00 & 1,21 \\
15 & 2.00 & 18.00 & 16.00 & 3,67 \\
16 & 2.00 & 12.00 & 20.00 & 4,67 \\
17 & 1.50 & 15.00 & 18.00 & 0,51 \\
18 & 1.50 & 20.05 & 18.00 & 1,44 \\
19 & 1.50 & 15.00 & 21,36 & 1,74 \\
20 & 1.00 & 18.00 & 16.00 & 0,3 \\
\hline
\end{tabular}

Zhoa dkk. (2011) menyebutkan bahwa p-value merupakan alat untuk mengetahui kesesuaian model, semakin kecil nilai p-value semakin signifikan model tersebut. Nilai p-value berdasarkan sequential model sum of square menunjukkan bahwa model yang signifikan dan disarankan pada respons adalah kuadratik, karena nilai p-value < 0,0001 (Tabel 3). Hal ini sesuai dengan pernyataan Bradley (2007) dan Sun dkk. (2011) yang menyebutkan apabila nilai $p$ value kurang dari 0,05 menunjukkan model bersifat signifikan dan berpengaruh lebih besar pada respons daripada model yang lain.

Perhitungan ketidaktepatan model (lack of fit test) adalah > 0,05 yaitu 0,1056 (Tabel 5). Berdasarkan lack of fit tests, model yang dianjurkan pada ketiga respons adalah kuadratik. Model akan dianggap tepat apabila lack of fit test dari model bersifat tidak nyata (tidak signifikan) secara statistik pada taraf $\alpha$ tertentu (Bas dan Boyaci, 2007). Pada kasus ini $\alpha$ yang digunakan adalah 0,05 . Proses pemilihan model berdasarkan ringkasan model secara statistik (model summary statistics) menunjukkan bahwa model yang memenuhi kriteria adalah model kuadratik (Tabel 4). Berdasarkan tiga proses pemilihan model tersebut 
model yang sesuai untuk penurunan kalsium oksalat pada proses penepungan adalah model kuadratik. Hasil analisis ragam dari permukaan respons kuadratik menunjukkan model kuadratik mempunyai pengaruh yang nyata terhadap respons.

Berdasarkan ringkasan statistik, model kuadratik mempunyai standar deviasi 0,3 dan $R$ = 0,9792 (Tabel 4). Zhoa dkk. (2011) menjelaskan bahwa nilai $R^{2}$ mendekati 1 mengindikasikan derajat korelasi yang tinggi antara observasi dan nilai prediksi. Hasil analisa menyebutkan nilai Adj. $R^{2}$ sebesar 0,9574 (Tabel 4). Hal ini memberi pengertian variabel berat chip porang, lama dan kecepatan penumbukan berpengaruh terhadap keragaman respons sebesar 95,74\% sedangkan sisanya sebesar $4,26 \%$ dipengaruhi faktor lain yang tidak dijadikan variabel yang diteliti.

Hasil analisis ragam (Tabel 5) menunjukkan bahwa berat (linier), interaksi berat dengan waktu, interaksi waktu dengan kecepatan, berat (kuadrat), waktu (kuadrat) dan kecepatan (kuadrat) berpengaruh nyata terhadap respons. Faktor lain yaitu waktu (linier), kecepatan (linier), interaksi berat dengan kecepatan yang dikaji tidak mempengaruhi respons.

Nyoman (2010) memperlihatkan bahwa berat chip sangat mempengaruhi penurunan kalsium oksalat pada proses penepungan, umumnya makin sedikit berat chip yang ditumbuk maka makin menurun kandungan kalsium oksalat pada glukomanan dengan waktu dan kecepatan yang sama. Makin sedikit chip yang ditumbuk kemungkinan kontak antara permukaan stamp mill dengan permukaan tepung yang ditumbuk lebih sering dan merata mengenai permukaan granula glukomanan sehingga kalsium oksalat lepas dan dengan bantuan blower kalsium oksalat dipisahkan. Oscarsson dan Savage (2007) juga menyebutkan konsentrasi kalsiumoksalat yang tinggi dan berbentuk tajam terletak di dekat kulit umbi, apabila ditekan terus-menerus akan memudahkan kalsium oksalat lepas dari komponen glukomanan.

Tabel 5. Analisis Ragam untuk Saponifikasi-Ekstraksi Satu Tahap Kedelai Varietas Lokal

\begin{tabular}{lcrcrc}
\hline Sumber & $\begin{array}{c}\text { Jumlah } \\
\text { Kuadrat }\end{array}$ & db & $\begin{array}{c}\text { Kuadrat } \\
\text { Tengah }\end{array}$ & Nilai F & $\begin{array}{c}\text { p-value } \\
\text { Prob > F }\end{array}$ \\
\hline Model & 40.71 & 9 & 4,63 & 52.43 & $<0,0001$ \\
A-Berat & 26,09 & 1 & 26,09 & 295.22 & $<0,0001$ \\
B-Waktu & 0.39 & 1 & 0.39 & 4,46 & 0,06 \\
C-Kec. & 0.11 & 1 & 0.11 & 1,22 & 0.2647 \\
AB & 1,9 & 1 & 1,9 & 21,51 & 0.0009 \\
AC & 0.031 & 1 & 0.031 & 0,35 & 0.5653 \\
BC & 1,28 & 1 & 1,28 & 14,48 & 0.0035 \\
A $^{2}$ & 8,72 & 1 & 8,72 & 98,7 & $<0.0001$ \\
B $^{2}$ & 2,24 & 1 & 2,24 & 25,37 & 0.0005 \\
C $^{2}$ & 2,89 & 1 & 2,89 & 32,65 & 0.0002 \\
Residual & 0.88 & 10 & 0,09 & & \\
Lack of Fit & 0.68 & 5 & 0,14 & 3,35 & 0.1056 \\
Galat & 0.20 & 5 & 0,04 & & \\
\hline
\end{tabular}

Gossy (2009) dan Nyoman (2010) menerangkan bahwa proses pembuatan tepung porang, ditepungkan dan dipisahkan dengan metode hembusan. Butiran tepung porang yang lebih berat (yang mengandung glukomanan) terpisahkan dari tepung kering, sehingga konsentrasi glukomanan meningkat. Partikel yang memiliki densitas dan ukuran lebih besar akan turun/masuk ke penampungan berdasarkan gravitasi, sedangkan pertikel yang lebih kecil dan ringan akan bergerak seiring dengan hembusan angin, meninggalkan pusat ruangan pemisah (Barbosa dkk., 2005).

Tabel 3. Sequential Model Sum of Squares Respons Kadar Kalsium Oksalat

\begin{tabular}{lcccccc}
\hline Sumber keragaman & Jumlah kuadrat & Derajat bebas & Kuadrat tengah & F Hitung & p-value Prob > F & Keterangan \\
\hline Mean & 55,18 & 1 & 55,18 & & & \\
Linier & 26,59 & 3 & 8,86 & 8,87 & 0,0011 & \\
2FI & 3,21 & 3 & 1,07 & 1,09 & 0,3884 & \\
Kuadratik & $\underline{11,9}$ & $\underline{3}$ & $\underline{3,97}$ & $\underline{44,88}$ & $\underline{3,0001}$ & $\underline{\text { Suggested }}$ \\
Kubik & 0,61 & 4 & 0,15 & 3,32 & 0,0924 & Aliased \\
Sisa & 0,28 & 6 & 0,046 & & & \\
\hline Total & 97,77 & 20 & 4,89 & & & \\
\hline
\end{tabular}

Tabel 4. Model Summary Statistics Respons Kadar Kalsium Oksalat

\begin{tabular}{|c|c|c|c|c|c|c|}
\hline Sumber keragaman & Standar deviasi & $\mathbf{R}^{2}$ & $\operatorname{Adj} R^{2}$ & Pred. $R^{2}$ & PRESS & Keterangan \\
\hline Linier & 1 & 0,6244 & 0,554 & 0,4372 & 23,97 & \\
\hline $2 \mathrm{FI}$ & 0,99 & 0,6998 & 0,5613 & 0,2584 & 31,58 & \\
\hline Kuadratik & $\underline{0,3}$ & $\underline{0,9792}$ & $\underline{0,9606}$ & $\underline{0,8495}$ & $\underline{6,41}$ & Suggested \\
\hline Kubik & 0,21 & 0,9935 & 0,9796 & 0,6225 & 16,08 & Aliased \\
\hline
\end{tabular}




\section{Permukaan Respons dan Titik Optimum}

Persamaan kuadratik dapat digunakan untuk memprediksi respons dari berbagai taraf, berat chip porang, lama dan kecepatan. Persamaan kuadratik yang diperoleh adalah: $\mathrm{Y}=0,55+1,38 \mathrm{X}_{1}-0,17 \mathrm{X}_{2}$ $0.089 \mathrm{X}_{3}-0,49 \mathrm{X}_{1} \mathrm{X}_{2}-0,062 \mathrm{X}_{1} \mathrm{X}_{3}-0,4 \mathrm{X}_{2} \mathrm{X}_{3+} 0,78 \mathrm{X}_{1}^{2}+$ $0,39 \mathrm{X}_{2}{ }^{2}+0,45 \mathrm{X}_{3}{ }^{2}$ dengan $\mathrm{X}_{1}=$ berat chip, $\mathrm{X}_{2}=$ lama penepungan, dan $\mathrm{X}_{3}=$ kecepatan.

Berhubung pada penelitian ini ada tiga faktor yang dikaji, maka terdapat tiga grafik respons yang menggambarkan hubungan antara berat chip porang, lama penumbukan, dan kecepatan penumbukan. Gambar 1 menunjukkan hubungan antara berat chip porang dan waktu penumbukan. Dari Gambar 1 diketahui bahwa pengaruh berat chip porang dan waktu penumbukan bersifat kuadratik terhadap respons kadar kalsium oksalat. Gambar 2 menunjukkan hubungan antara berat chip porang dan kecepatan penumbukan. Dari Gambar 2 terlihat bahwa pengaruh berat chip porang dan kecepatan penumbukan bersifat kuadratik terhadap respons kadar kalsium oksalat. Gambar 3 menunjukkan pengaruh waktu dan kecepatan penumbukan terhadap kadar kalsium oksalat dalam tepung porang yang dihasilkan. Pengaruh kedua variabel tersebut terhadap respons bersifat kuadratik.

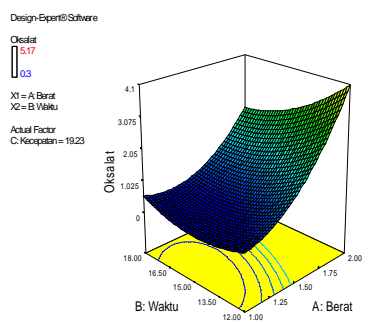

A
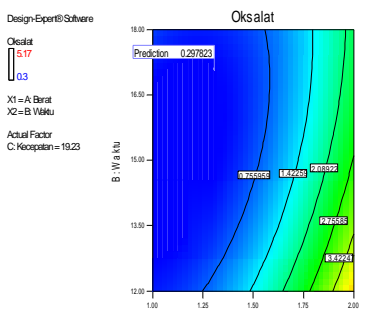

A: Berat
Gambar 1. Grafik Respons (A) dan Kontur (B) Hubungan antara Berat dan Waktu Penumbukan Chip Porang Optimasi Penurunan Kalsium Oksalat pada Proses Produksi Tepung Porang

Pengaruh variabel berat chip porang, lama penumbukan dan kecepatan penumbukan terhadap respons dapat dilihat dengan mengikuti garis horizontal putus-putus sejajar sumbu X (Gambar 1, 2 dan 3). Respons akan terus menurun dengan menurunnya berat chip porang, meningkatnya waktu dan kecepatan penumbukan sampai diperoleh respons terendah. Jika berat chip porang terus diturunkan, respons tidak mengalami penurunan lagi, sedangkan waktu dan kecepatan penumbukan apabila semakin ditingkatkan maka respons mengalami peningkatan namun pada berat chip porang yang tinggi. Hal ini

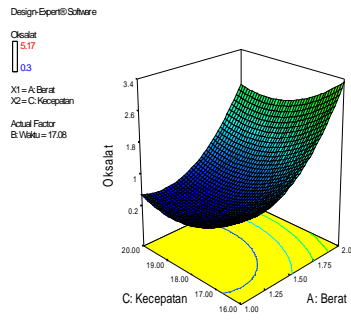

A
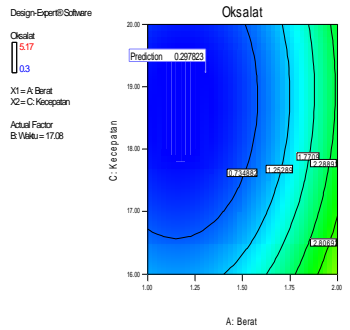

B
Gambar 2. Grafik Respon (A) dan Kontur (B) Hubungan antara Berat dan Kecepatan Penumbukan Chip Porang Optimasi Penurunan Kalsium Oksalat Pada Proses Produksi Tepung Porang

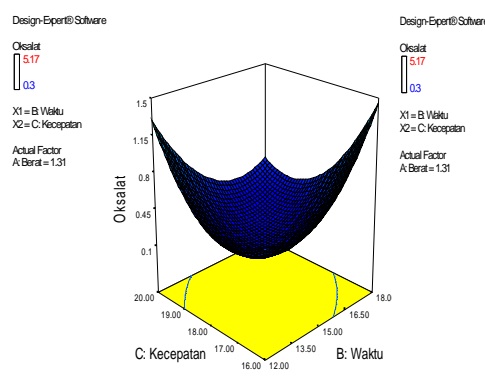

A

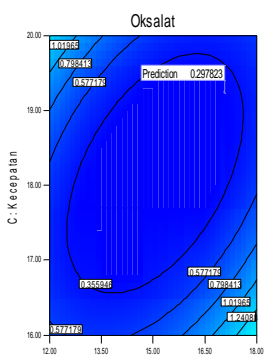

B: Waktu

B
Gambar 3. Grafik Respons (A) dan Kontur (B) Hubungan antara Waktu dan Kecepatan Penumbukan Chip Porang Optimasi Penurunan Kalsium Oksalat pada Proses Produksi Tepung Porang

mungkin disebabkan berhubungan dengan kekuatan dari stamp mill dan kontak antara tepung dengan permukaan penumbuk stamp mill kurang merata atau jumlah chip yang ditumbuk telah mencapai optimal. Gossy (2009) juga berpendapat bahwa penumbukan $250 \mathrm{gr}$ chip porang dengan waktu 225 menit dan 270 menit tidak mengalami penurunan kalsium oksalat.

Penurunan berat chip porang menyebabkan makin cepatnya terjadi penghancuran chip dan makin luasnya permukaan granula glukomanan yang ditekan, dengan meneruskan penumbukan maka makin mudahnya lepas kalsium oksalat dari granula dan makin menurunnya kadar kalsium oksalat dari tepung porang. Komponen non glukomanan menempel kuat dalam matrik dinding kantong glukomanan. Kantung glukomanan lebih tahan terhadap penumbukan dibanding komponen lain yang menempel pada kantung glukomanan. Dengan adanya penumbukan yang terus menerus maka komponen non-glukomanan secara bertahap akan pecah/hancur sehingga lepas dari kantung glukomanan sedangkan kantung glukomanannya 
sendiri tetap utuh. Komponen non-glukomanan (kalsium oksalat, pati, dan protein) yang pecah dan lepas dari kantung glukomanan akan terhembus keluar pada saat penumbukan karena adanya "penghembus" yang menempel pada kepala penumbuk, dan juga bisa terhembus keluar saat dilakukan metode hembusan menggunakan blower.

Bas dan Boyaci (2007) menyebutkan bahwa analisis kanonik terhadap model polinomial kuadratik digunakan untuk menentukan bentuk dan kurva permukaan respons, serta letak titk stasioner atau titik optimum. Analisis kanonik merupakan pendekatan matematik yang digunakan untuk menentukan letak titik stasioner dari permukaan respons dan untuk mengetahui apakah respons bersifat minimum atau maksimum. Nilai sebenarnya untuk titik stasioner yang diperoleh dari hasil analisis kanonik adalah berat chip porang $1,31 \mathrm{~kg}$, lama penumbukan 17 jam, 4 menit 8 detik $(17,08$ jam), dan kecepatan penumbukan 19,23. Respons kadar kalsium oksalat (\%) pada kondisi optimum ini diprediksi sebesar 0,2978\%. Kondisi ini merupakan kondisi terbaik untuk mendapatkan kadar kalsium oksalat terendah dalam tepung porang dari hasil penepungan chip porang metode mekanis.

\section{Karakteristik Tepung Porang Kondisi Optimum Penurunan Kalsium Oksalat}

Tabel 5 diketahui bahwa proses mekanis penepungan chip porang dapat menurunkan pengotor pada tepung porang. Penurunan kalsium oksalat dari $6,11 \%$ menjadi $0,2978 \%$ sangat signifikan $(95,12 \%)$ namun belum seperti tepung glukomanan komersial. Penurunan kadar kalsium oksalat juga dapat dilihat pada Gambar 4 pengamatan dengan mikroskop cahaya dengan perbesaran 100x dan Gambar 7 pengamatan menggunakan SEM.

Pengamatan pada tepung porang hasil optimasi penurunan oksalat menunjukkan bahwa kalsium oksalat yang terdapat pada permukaan granula glukomanan sudah jauh berkurang dibandingkan dari pada tepung porang penepungan dengan berat chip porang $2,34 \mathrm{~kg}$, waktu penepungan 15 jam dan kecepatan 18 (Gambar 4). Hal ini terlihat pada banyaknya area berwarna hitam di bagian luar granula glukomanan, dan setelah diamati dengan perbesaran 1000× dapat dilihat juga bahwa kalsium oksalat pada tepung porang berbentuk jarum (Gambar 5). Bentuk kristal kalsium oksalat akan tampak lebih jelas berupa jarum pada pengamatan SEM (Gambar 7). Tabel 4, Gambar 4, Gambar 5, dan Gambar 7 menunjukkan sinkronisasi dari data pengamatan secara visual dengan data yang diperoleh secara kuantitatif melalui analisis kimiawi.
Tabel 6. Karakteristik Kimia dan Fisik Chip Porang, Tepung Porang Hasil Optimasi Penurunan Kadar Kalsium Oksalat dengan Metode Mekanis dan Glukoman Komersial

\begin{tabular}{lccc}
\hline \multicolumn{1}{c}{$\begin{array}{c}\text { Para } \\
\text { Meter }\end{array}$} & $\begin{array}{c}\text { Chip } \\
\text { porang (\%) }\end{array}$ & $\begin{array}{c}\text { Tepung porang } \\
\text { optimasi (\%) }\end{array}$ & $\begin{array}{c}\text { Glukomanan } \\
\text { Komersial (\%) }\end{array}$ \\
\hline Pati & 16,21 & 2,5 & 0,27 \\
Protein & 4,5 & 2,3 & 0,63 \\
Lemak & 3.14 & 1,57 & 0,79 \\
Abu & 7,72 & 2,35 & 0,37 \\
Air & 9,48 & 10,18 & 8,25 \\
Ca-oksalat & 6,11 & 0,3 & 0,08 \\
Glukomanan & 37,54 & 65,27 & 92,51 \\
Viskositas & 2900 & $6300^{*}$ & $13000^{*}$ \\
Drajat putih & - & $47,09^{* *}$ & $62,86^{* *}$ \\
\hline
\end{tabular}

Keterangan:

* dalam c.Ps dengan konsentrasi larutan 1\%

** tanpa satuan, dimana nilai 100 diasumsikan sebagai warna putih

Kalsium oksalat merupakan salah satu senyawa yang tidak diharapkan pada tepung porang. Efek kronis konsumsi bahan pangan yang mengandung oksalat adalah terjadinya endapan kristal kalsium oksalat dalam ginjal dan membentuk batu ginjal. Menurut Noor (2002), dosis yang mampu menyebabkan pengaruh yang fatal adalah antara 10-15 g, sementara Li dkk. (2010) menyebutkan bahwa asupan harian oksalat maksimum sebesar $70-150 \mathrm{mg} / \mathrm{hari}$.

Kadar glukomanan tepung porang hasil optimasi menunjukkan peningkatan jika dibandingkan dengan chip porang dari $37,54 \%$ menjadi $65,27 \%$. Peningkatan ini diimbangi dengan semakin menurunnya komponen-komponen non glukomanan lainnya, seperti kadar oksalat, kadar protein, kadar lemak, kadar abu dan kadar pati (Tabel 4). Kadar glukomanan baru mencapai 65,27\%, untuk mendapatkan kadar yang lebih tinggi seperti glukomanan komersial perlu dilakukan pemurnian selanjutnya. Takigami (2000) melaporkan bahwa proses penepungan masih membutuhkan pemurnian tepung porang dengan pencucian etanol untuk mengurangi komponen-komponen pengotor yang berada di permukaan granula glukomanan. Mengacu pada standar mutu internasional tepung porang (Professional Standart of the People' Republic of China for Konjac Flour, 2002) kadar glukomanan tepung porang pada proses ini belum memenuhi kualitas top grade (lebih dari $70 \%$ ).

Kadar air mengalami peningkatan dari 9,48\% pada chip porang menjadi $10,14 \%$ pada tepung hasil optimasi dan 8,25\% pada tepung glukomanan komersial. Hal tersebut diduga disebabkan oleh kurang optimumnya proses pengeringan yang 


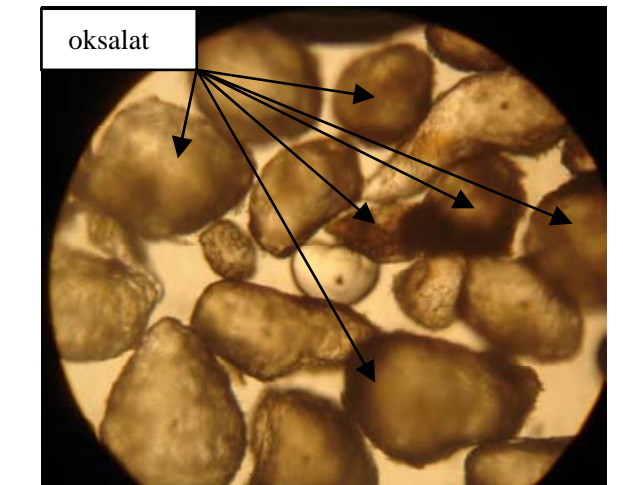

Tepung porang 2,34 kg 15 jam dan kecepatan 18

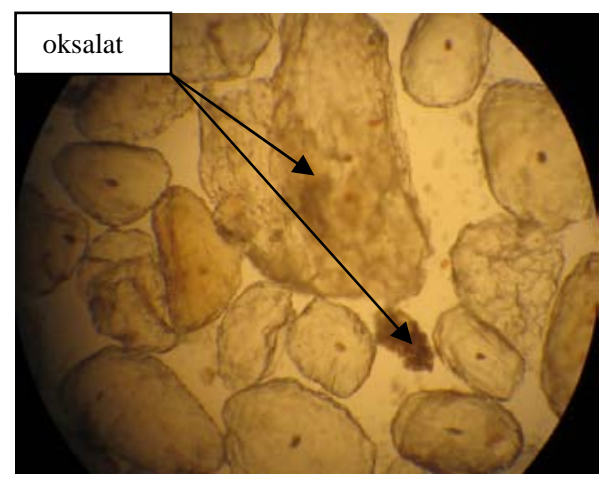

Optimasi penurunan kalsium oksalat $\left(1,3 \mathrm{~kg}, 17,4^{\prime} 8^{\prime \prime}, \mathrm{kec} 19,23\right)$

Gambar 4. Granula Glukomanan Menggunakan Mikroskop Cahaya Perbesaran 100 Kali

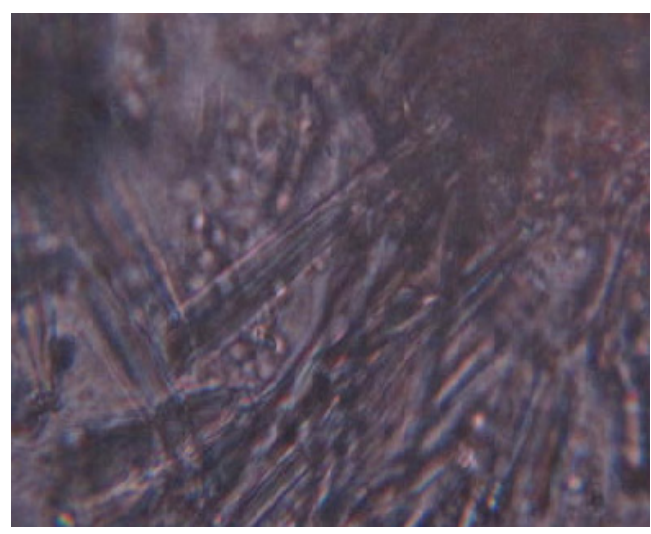

Gambar 5. Pengamatan Bentuk Kristal Kalsium Oksalat dengan Mikroskop Cahaya Perbesaran 1000 Kali

dilakukan, sehingga masih banyak air yang terperangkap di dalam bahan. Analisa kadar air dilakukan setelah beberapa lama tepung hasil optimasi disimpan atau perbedaan waktu analisa kadar air setelah pengeringan juga dapat menyebabkan perbedaan kadar air

Viskositas tepung porang hasil optimasi (6300 c.Ps) lebih tinggi daripada tepung chip porang (2900 c.Ps) namun masih rendah dibandingkan viskositas tepung komersial (13000 c.Ps). Tinggi rendahnya viskositas tepung porang erat kaitannya dengan kadar glukomanan yang terkandung di dalamnya. Hal tersebut menunjukkan bahwa proses penepungan mampu meningkatkan kadar kemurnian glukomanan sehingga viskositasnya meningkat.
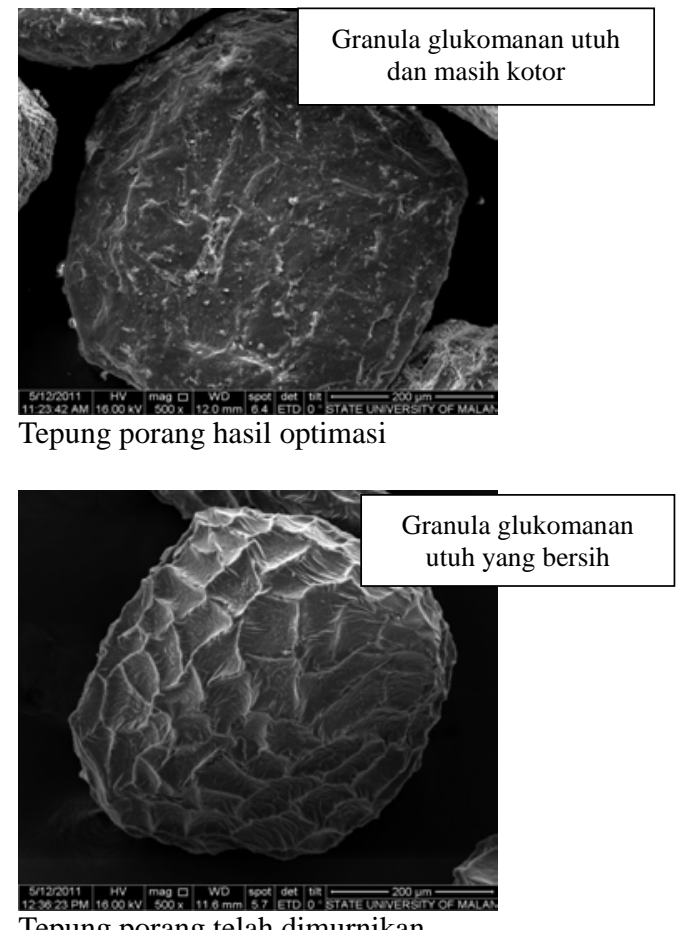

Tepung porang telah dimurnikan

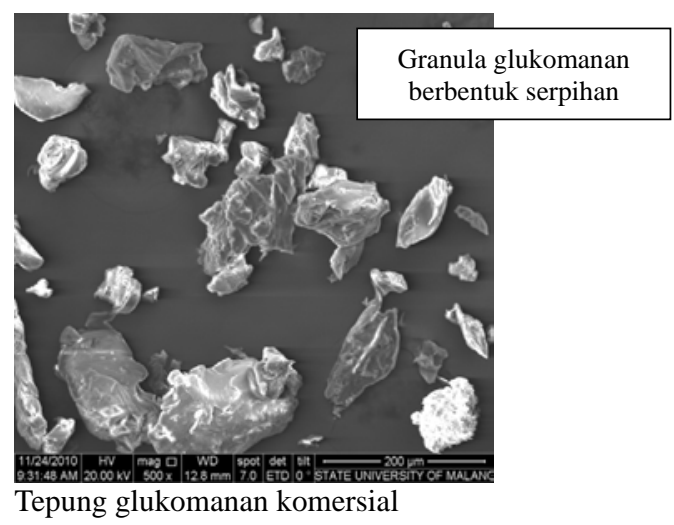

Gambar 6. Pengamatan SEM Tepung dengan Perbesaran 500 kali

Bentuk granula pada tepung porang juga tampak lebih utuh dan seragam jika dibandingkan dengan tepung glukomanan komersial. Pada tepung glukomanan komersial bentuk granulanya tampak telah hancur menjadi serpihan-serpihan yang tidak beraturan. Bentuk granula yang berbeda ini diduga terjadi karena perbedaan cara pengolahan dari umbi porang menjadi tepung, seperti ditampilkan pada Gambar 6 dengan perbesaran 500 kali pada luas bidang pengamatan $200 \mu \mathrm{m}$. Gambar 6 juga memperlihatkan bahwa granula tepung porang hasil 
optimasi penepungan masih mengandung pengotor dibandingkan tepung granula yang telah mengalami pemurnian.

Perbesaran dilanjutkan sampai 2000 kali dengan luas bidang pengamatan $50 \mu \mathrm{m}$. Gambar 7 menunjukkan bahwa proses mekanis belum mampu membersihkan komponen-komponen pengotor yang menyelimuti permukaan granula glukomanan atau masih banyak mengandung pengotor, bahkan tampak kristal kalsium oksalat berbentuk jarum yang masih menempel. Takigami (2000) melakukan pencucian tepung porang dengan larutan etanol untuk menghilangkan komponen mikro yang ada di permukaan granula glukomanan dan bahan-bahan pengotor yang terperangkap di dalam partikel glukomanan.
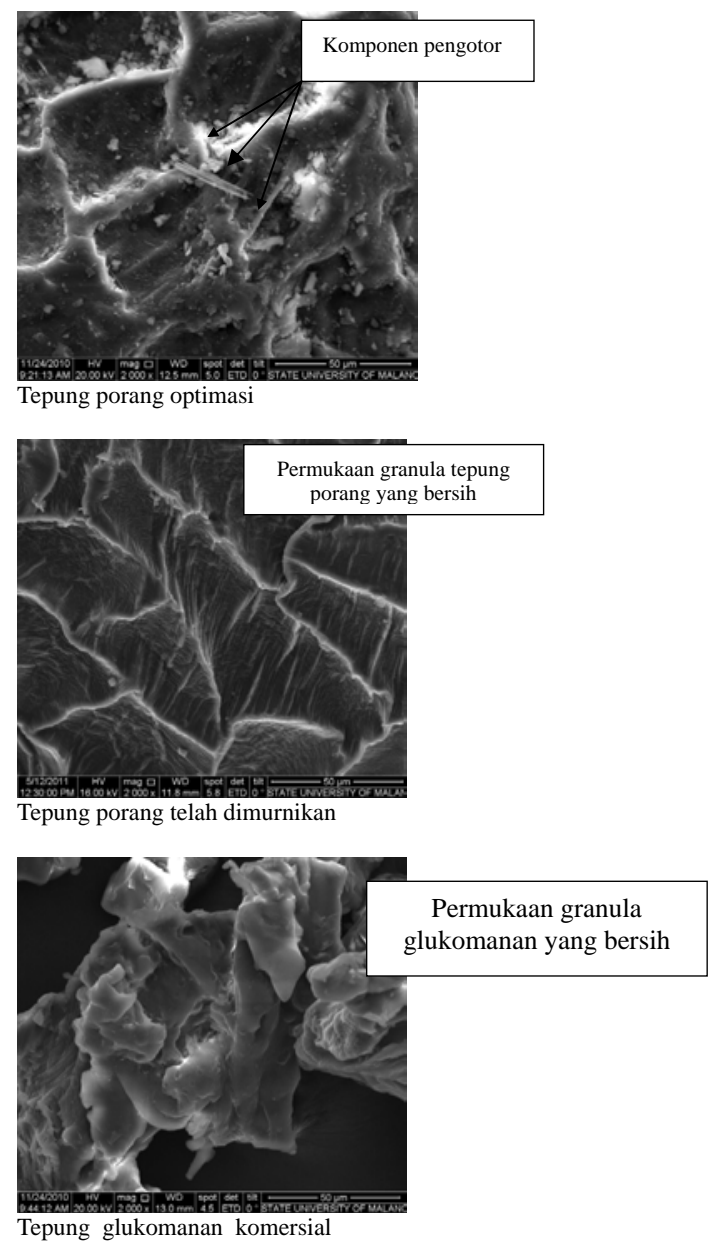

Gambar 7. Pengamatan SEM Tepung dengan Perbesaran 2000 kali

\section{SIMPULAN}

Optimasi penurunan kalsium oksalat pada proses penepungan untuk memproduksi tepung porang dari chip porang dengan metode mekanis menunjukkan bahwa berat chip porang, lama dan kecepatan penumbukan berpengaruh terhadap respons kadar kalsium oksalat. Respons yang diperoleh bersifat kuadratik dengan persamaan polinomial yang diperoleh adalah: $\mathrm{Y}=0,55+1,38 \mathrm{X}_{1}-0,17 \mathrm{X}_{2}$ - $0.089 \mathrm{X}_{3}-0,49 \mathrm{X}_{1} \mathrm{X}_{2}-0,062 \mathrm{X}_{1} \mathrm{X}_{3}-0,4 \mathrm{X}_{2} \mathrm{X}_{3+} 0,78 \mathrm{X}_{1}^{2}$ $+0,39 \mathrm{X}_{2}^{2}+0,45 \mathrm{X}_{3}^{2}$ dengan $\mathrm{X}_{1}=$ berat chip, $\mathrm{X}_{2}=$ lama penepungan, dan $\mathrm{X}_{3}=$ kecepatan. Pada kondisi optimum respons kadar kalsium oksalat diprediksi sebesar $0,2978 \%$. Hasil verifikasi menunjukkan bahwa chip porang dalam bentuk tepung porang yang ditumbuk dengan metode mekanis mempunyai kadar kalsium oksalat yang diperoleh 0,3\%.

\section{DAFTAR PUSTAKA}

Barbosa, G.V., O.R. Enrique, P. Julianto, dan H. Yan, 2005. Food Powder. Kluwer Academic Plenum Publisher.

Bas, D., dan Boyaci, I.S., 2007. Modeling and Optimization I: Usability of response surface methodology. Journal of Food Engineering, 78, 836-845.

Bhandari, A., Koul, S., dan Sekhon, A., 2002. Effects of Oxalate on HK-2 Cells, a Line of Proximal Tubular Epithelial Cells from Normal Human Kidney. Journal Urol, 168, 253-259.

Bradley, N., 2007. The Response Surface Methodology. Thesis of Department of Mathematical Sciences Indiana University of South Bend. Indiana.

Eri, P.A., 2007. Kaji Tindak Pembuatan Tepung Porang dengan Hummer Mill dengan Metode Hembusan dan Proses Pemanasan untuk Menghilangkan Rasa Gatal. Laporan Penelitian. FTP-UNIBRAW.

Gao, S.J, dan Nishinari, K., 2004. Effect of Degree of Acetilation on Gelation of Konjac Glucomannan. Biomacromolecules, 5, 175-185.

Gossy, A., 2009. Uji Kerja Perancangan Mesin Stamp Mill Penumbuk 3 Lesung untuk Chip Porang. Laporan penelitian. FTP-UNIBRAW.

Katsuraya, K., Okuyama, K., Hatanaka, K., Oshima K., Sato, T., dan Matsuzaki, K., 2003. Contitution of Konjac Glucomannan: Chemical Analysis and ${ }^{13} \mathrm{C}$ NMR Spectroscopy. Carbohydrate polymers, 53, 183-189.

Li, S., Xie, A., Shen, Y., Yu, X. dan Hu, G., 2010. Biogenic Synthesis of Calcium Oxalate Crystal by Reaction of Calcium Ions with Spinach Lixivium. Colloids and Surfaces B: Biointerfaces, 78, 229-236.

Montgomery, D.C., 2003. Design and Analysis of Experiments. $5^{\text {th }}$ ed. John Wiley \& Sons. Singapore.

Nakata, P.A., 2003. Advances in Our Understanding of Calcium Oxalate Crystal Formation and Function in Plant. Journal Plant Science, 164, 901-909.

Noor, Z. 2002. Senyawa Anti Gizi. Pusat Antar Universitas Pangan dan Gizi. UGM. Yogyakarta.

Nyoman, O.S.D, 2010. Proses Penepungan dengan Metode Stamp Mill dan Pemurnian Glukomanan dengan Metode Ekstraksi Etanol Bertingkat untuk Pengembangan Industri Tepung Porang. Laporan Penelitian. THP. UNIBRAW. 
Oscarsson, K.V., dan Savage, G.P., 2007. Composition and Availability of Soluble and Insoluble Oxalates in Raw and Cooked Taro (Colocasia Esculenta Var. Schott) Leaves. Food Chemistry, 101, 559-562.

Professional Standard of the People Republic of China. 2002. Konjac Flour. Promulgated by the Ministry of the People's Republic of China. Beijing.

Sun, J., Guoyuo, Y., Peng, D., dan Lanying, C., 2011. Optimization of Extraction Technique of Polysaccharides from Pumpkin by Response Surface Method. Journal of Medicinal Plants Research, 5 (11), 2218-2222.

Takigami, S. 2000. Handbook of Hydrocolloids: Konjak Mannan. CRC Press. Washington DC.
Yang, X. H., Zhu, W.L., dan Yan, J.F., 2006. A TimeTemperature Rheological Study of Konjac Glucomannan Hydrocolloid. Journal of Biomaterial Science, 17 (1-2), 53-59.

Zhao, Q., J.F. Kennedy, dan X. Wang, 2011. Optimization of Ultrasonic Circulating Extraction of Polysaccharides from Asparagus Officinalis Using Response Surface Methodology. International Journal of Biological Macromolecules, 49, 181-187.

Zhang, Y., Xie, B., dan Gan, X., 2005. Advance in Application of Konjac Glucomannan and its Derivatives. Carbohydrate Polimers, 60, 27-31. 